\title{
PENDAMPINGAN \& PELATIHAN BERWIRAUSAHA IBU-IBU PETANI JAGUNG
}

\author{
Usman $^{1}$, Veneranda Rini Hapsari ${ }^{2}$ \\ ${ }^{12}$ Sekolah Tinggi Ilmu Manajemen Shanti Bhuana \\ Email: yohanes.usman@shantibhuna.ac.id \\ rini@shantibhuana.ac.id
}

\begin{abstract}
The problem with corn farmers is that the quality of corn prices does not match the market prices because they do not do the drying, so prices in the market have dropped considerably. The role of corn is very important and beneficial for human and animal life. And it is the second staple food after rice. While in the world corn ranks third after wheat and rice. The advantage of corn itself is that the harvest time is faster and very resistant to pests and diseases and higher production. (Ermanita, 2004.Indonesia is a tropical climate and the land is fertile. and the Indonesian nation is an agrarian country, known for its rich biodiversity, in the fields of food, industry and energy... The method used in this service is a method of training and teaching that is discussion, teaching method, participants of the training are housewives in the Farmer Business group. They are given material about how to make cakes so that they can be of selling value., Using the method (Discussion Method) Trainees are given the opportunity to discuss issues related to corn, using the interview method. The trainees were given the opportunity to be interviewed how much influence the training on baking for them in developing themselves.conclusion is Broadly speaking, the response of the community represented by housewives to the training of making cakes is very extraordinary, so it is hoped that this activity can continue until a goal where the community can understand well that the opportunity for entrepreneurship is always there if there is a desire to do in daily life.
\end{abstract}

Keywords: Assistance, Entrepreneurship,Training for corn farmers

\begin{abstract}
Abstrak: Masalah dari petani jagung adalah kwalitas harga jagung tidak sesuai dengan harga pasar karena mereka tidak melakukan pengeringan,sehingga harga di pasarpun merosot jauh. Peran jagung sangat penting dan bermanfaat bagi kehidupan manusia maupun hewan.dan merupakan makanan pokok kedua setelah padi. Sedangkan didunia jagung menduduki urutan ketiga setelah gandum dan padi. Keunggulan jagung itu sendiri adalah masa panen lebih cepat dan sangat tahan terhadap serangan hama dan penyakit dan produksi lebih tinggi. (Ermanita,2004).Indonesia merupakan iklim tropis dan tanahnya subur. dan bangsa Indonesia merupakan negara agraris, dikenal dengan kaya akan hayati, dalam bidang pangan,industry dan energi. Sebagai bahan industry jagung dapat diolah menjadi olahan minyak,tepung jagung,gula dan lain-lainya. Metode yang dipakai dalam pengabdian ini adalah metode pelatihan dan pengajaran yang bersifat diskusi,Metode mengajar,Peserta pelatihan adalah ibu-ibu Rumah tangga kelompok Usaha Tani.Mereka diberikan materi tentang bagaimana cara pembuatan kue agar bisa bernilai jual.,Menggunakan metode (Metode diskusi) Peserta pelatihan diberikan
\end{abstract}


kesempatan untuk mendiskusikan permasalahan yang berkaitan dengan jagung,Menggunakan metode wawancara. Peserta Pelatihan di beri kesempatan untuk diwawancara sebeberapa besar pengaruh pelatihan pembuatan kue bagi mereka dalam mengembangkan diri. Kue yang berbahan dasar jagung setelah di olah dan hasilnya memuaskan dengan cita rasa yang kas serta rasanya enak dan aromanyapun kas jagung masih sangat terasa. Secara garis besar kesimpulan bahwa respon masyarakat yang di wakili para ibu-ibu rumah tangga terhadap pelatihan pembuatan kue sangat luar biasa,maka di harapkan kegiatan ini bisa berlanjut sampai pada suatu tujuan dimana masyarakat dapat memahami dengan baik kalau peluang berwirausaha itu selalu ada apabila ada keinginan untuk melakukan dalam kehidupan sehari-hari.

Kata Kunci: Pendampingan,Pelatihan,berwirausaha,ibu-ibu petani jagung 


\section{PENDAHULUAN}

Tanaman jagung merupakan salah satu komoditas unggulan kedua di Indonesia setelah beras. Jagung merupakan salah satu jenis makanan pengganti beras. Jagung memiliki potensi yang sangat besar karena memiliki kandungan Nutrisi yang sangat komplek apabila dibandingkan dengan beras dan ramah terhadap lingkungan, Hendriadi (2013) mengungkapkan bahwa untuk pengembangan system dalam usahatani yang ramah lingkungan mestinya harus sejalan dengan kebijakan Badan Litbang Pertanian yang telah dirumuskan dengan Model Perencanaan Pembangunan Pertanian yang ramah lingkungan. Peningkatan pertumbuhan usaha tani jagung lebih disebabkan perkembangan permintaan pakan ternak dan didorong inovasi teknologi benih unggul jagung jenis hibrida,serta beberapa perusahaan swasta (Mawardi et al. 2008) jagung memiliki Kandungan zat yang banyak, seperti karbohidrat, serat, vitamin, kalium, asam linoleat,asam folat, beta karoten, mineral, dan protein membuat jagung dikenal sebagai bahan pangan yang cukup berkhasiat untuk mencegah beberapa penyakit. Menurut Efendi (2015), manfaat jagung bagi kesehatan berdasarkan kandungan nutrisinya dapat melawan beberapa penyakit seperti melawan kanker, mencegah anemia, sebagai sistem imun, sumber asam linoleat, sumber kalium, sumber vitamin sumber asam pentotenat (vitamin B5), sumber asam folat, sumber beta karoten,sumber serat, sumber mineral, sumber protein, dan sumber pigmen fenolik flavonoid.Menurut Jumadi (2008:73-74), jagung dapat diolah menjadi berbagai produk olahan. Salah satu hasil olahan jagung yang disukai banyak konsumen adalah emping jagung (Mangunwidjaja cit. Rahman, 2015). Proses pengolahan emping jagung cukup sederhana,sehingga berpeluang untuk diadopsi oleh masyarakat pedesaan, terutama perempuan petani,sebagai industri rumah tangga (home industry). Di dusun sempayuk ibu-ibu rumah tangga memiliki kelompok yang beranggotakan 25 orang dan sebagian besar kegiatan kelompok mereka melakukan kegiatan yang bersifat kekelurgaan dan saling membantu dalam hal melakukan kegiatan yang berkaitan yang sifatnya membangun ekonomi. Terkait dengan hal tersebut, agroindustry,menjadi usaha yang cukup penting untuk dilakukan dalam rangka meningkatkan nilai tambah, terutama pada saat produksi melimpah dan harga produk rendah. Menurut Rahman,(2015:108-111), kondisi tersebut merupakan saat yang tepat untuk mengolah jagung secara,lebih lanjut agar menjadi produk yang bernilai jual tinggi.

Analisa situasi : Desa Belimbing terletak tidak terlalu jauh dengan kecamatan Lumar dan lahan pertanian di desa tersebut lumayan luas dan masih produktif dan tanahnya lumayan subur. Didukung oleh keadaan curah hujan termasuk bagus sehingga sangat membantu untuk membuka lahan pertanian jagung dengan baik. Lahan pertanian di desa tersebut sangat luas dan subur dan diamnfaatkan secara umum. Para usahatani jagung lumayan baik hanya yang menjadi masalah adalah SDM mereka masih kurang. Memadai. Secara umum. Para petani menjual jagung mereka ke para 
Tengkulak dijual dalam bentuk jagung butiran,yaitu setelah panen langsung di jual. Mereka tidak menjual dalam bentuk makanan atau produk barang dan ketika di jual ke para Tenggkulak harga jagung akan menyusut dari harga pasaran. Salah satu yang menjadi masalah adalah kwalitas harga jagung tidak sesuai dengan harga pasar karena mereka tidak melakukan pengeringan dengan baik sehingga harga di pasarpun turun merosot jauh. Masalah harga juga menjadi salah satu masalah utama bagi masyarakat desa Belimbing itu sendiri. Pertanian merupakan salah satu bidang yang menopang kesejahteraaan masyarakat pedesaan. Bangsa Indonesia memiliki potensi sumber daya alam yang sangat luar biasa baik dalam bentuk jumlah maupun dalam bentuk keanekaragaman. Komuditas tanaman pangan yang mengambil peran dalam dunia pembangunan pertanian adalah jagung. Kebutuhan jagung dari tahun ketahun terus meningkat dan selalu sejalan dengan ekonomi masyrakat. Jaman yang serba modern ini kewirausahaan menjadi isu yang sangat penting dalam dunia pertanian. Tentunya petani sangat membutuhkan keterampilan yang didasari oleh kewirausahaan sehingga dapat membangun kepercayaan diri dan berani mengambil resiko serta memiliki orientasi untuk berprestasi serta memiliki kemampuan dalam mengambil keputusan. Menurut Onyebinama (2010) ketidak sanggupan petani untuk mendapat manfaat dalam rangka memerapkan ilmu pengetahuan dan tegnologi baru, merupakan tantangan yang harus di perjuangankan. Peran jagung sangat penting dan bermanfaat bagi kehidupan manusia maupun hewan.dan merupakan makanan pokok kedua setelah padi. Sedangkan didunia jagung menduduki urutan ketiga setelah gandum dan padi. Keunggulan jagung itu sendiri adalah masa panen lebih cepat dan sangat tahan terhadap serangan hama dan penyakit dan produksi lebih tinggi. (Ermanita,2004).Indonesia merupakan iklim tropis dan tanahnya subur dan sebagai negara yang di kenal negara agraris bangsa Indonesia merupakan negara yang dikenal dengan kaya akan hayati yang menjadi andalan dalam bidang pangan,industry dan energi. Sebagai bahan industry jagung dapat diolah menjadi olahan minyak,tepung jagung,gula dan lain-lainya. Perkembangan yang luar biasa adalah jagung digunakan sebagai bahan baku produksi etanol untuk bahan bakar (biofuel). Dampak penggunaan biofuel meningkat maka secara otomatis permintaan bahan bakunya yaitu jagung sangat meningkat dengan tajam pula. Maka produksi jagung dalam negeri perlu ditingkatkan,Jenis jagung yang dikembangkan di Indonesia. Melihat pengahsilan jagung di Kalbar termasuk bagus maka dalam pengabdian masyarakat ini penulis berkesempatan untuk melakukan hal yang berguna bagi masyarakat dengan pendampingan para ibu-ibu dari para petani jagung untuk mengolah jagung menjadi bahan makanan seperti kue bolu dan puding. Para ibu-ibu memberikan respon yang positif itu dapat terlihat dari antusias mereka untuk mengikuti pelatihan tsb. 


\section{METODE PELAKSANAAN}

Metode dalam kegiatan pengabdian ini melalui beberapa tahap :

a) Tahap persiapan

b) Tahap Survey

c) Tahap Pelaksanaan

1. Tahap Persiapan :Dalam tahap ini dilakukan berbagai persiapan seperti,persiapan alat-alat yang akan digunakan seperti dokumentasi,SDM,alat-alat lainya yang menunjang kegiatan.

2. Tahap Survey : Sebelum kegiatan dilakukan team datang ke lokasi untuk berkoordinasi terkait lokasi dan waktu yang akan di laksanakan kegiatan.

3. Tahap Pelaksanaan,Team pengabdian dari Shanti Bhuana melaksanakan kegiatan sesuai dengan arahan yang telah disepakati.Mulai dari pembicara dalam menyampaikan materi dan Sebagian dari team langsung memperagakan atau mempraktekkan cara pembuatan kue dari bahan dasar jagung.Metode pelaksanaan yang dilakukan adalah mengajar,Peserta pelatihan adalah ibu-ibu Rumah tangga kelompok Usaha Tani.Mereka diberikan materi tentang bagaimana cara pembuatan kue agar bisa bernilai jual.Peserta pelatihan diberikan kesempatan untuk mendiskusikan permasalahan yang berkaitan dengan jagung. wawancara. Peserta Pelatihan di beri kesempatan untuk diwawancara untk mengetahuai tanggapan para ib-ibu,seberapa penting bagi mereka akan kegiatan ini.

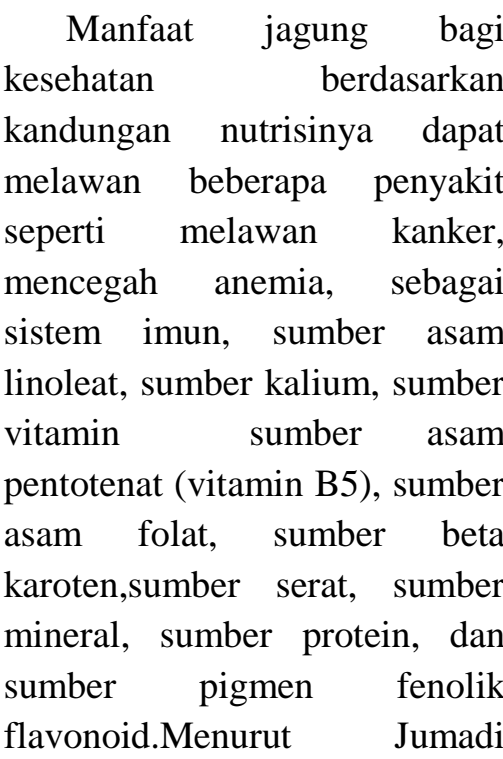
(2008:73-74), jagung dapat diolah menjadi berbagai produk olahan. Salah satu hasil olahan jagung yang disukai banyak konsumen adalah emping jagung (Mangunwidjaja cit. Rahman, 2015). Proses pengolahan emping jagung cukup sederhana,sehingga berpeluang untuk diadopsi oleh masyarakat pedesaan, terutama perempuan petani,sebagai industri rumah tangga (home industry). Di dusun sempayuk ibu-ibu rumah tangga memiliki kelompok yang beranggotakan 25 orang dan sebagian besar kegiatan kelompok mereka melakukan kegiatan yang bersifat kekelurgaan dan saling membantu dalam hal melakukan kegiatan yang berkaitan yang sifatnya membangun ekonomi. Terkait dengan hal tersebut, agroindustry,menjadi usaha 
yang cukup penting untuk dilakukan

dalam rangka meningkatkan nilai,tambah, terutama pada saat produksi melimpah dan harga produk rendah. Menurut Rahman,(2015:108111), kondisi tersebut merupakan saat yang tepat untuk mengolah jagung secara,lebih lanjut agar menjadi produk yang bernilai jual tinggi.

Analisa situasi : Desa Belimbing terletak tidak terlalu jauh dengan kecamatan Lumar dan lahan pertanian di desa tersebut lumayan luas dan masih produktif dan tanahnya lumayan subur. Didukung oleh keadaan iklim curah hujan termasuk bagus sehingga sangat membantu untuk membuka lahan pertanian jagung dengan baik. Lahan pertanian di desa tersebut sangat luas dan subur dan diamnfaatkan secara umum. Tani jagung menghasilkan dan tetap diminati oleh konsumen. Dengan konsep pendampingan tersebut. Masyarakat diharapkan tidak hanya mengerti tentang tahapan pemasaran hasil produk pertanian, tetapi dapat mempraktikkan secara langsung dalam tahapan pebuatan produk dari bahan dasar jagung yang memiliki cita rasa yang enak agar tidak kalah saing dengan jenis kue yang berbahan dasar terigu.

Dan diajarkan bagaimana cara memasarkan produk biar bisa laku di pasaran . Keterlibatan ibu-ibu rumah tangga ini diharapkan mampu mendorong semangat dari mereka masing-masing untuk berwirausaha.Pelatihan ini dilakukan dengan melibatkan masyarakat secara langsung dalam setiap proses atau tahapan pembuatan ataupun pemasaran produk.. Adapun teknik pengumpulan data dilakukan dengan terjun langsung dalam proses produksi pembuatan produk jagung. Survei juga dilakukan pada masyarakat sekitar dan pada KelompokWanita Gapok. Selaku perintis berdirinya usaha produksi kue yang berbahan dasar jagung. Kegiatan ini akan dilakukan selama 1 tahun , mulai dari bulan agustus 2019 sampai januar 2020.Kegiatan ini dilakukan di dusun sempayuk desa Belimbing kecamatan Lumar. Jagung Manis Merupakan jagung yang banyak di konsumsi masyarakat pada umumnya. Selain rasanya manis karena ada kandungan gula yang tinggi didalamnya. Dari hasil penelitian surtinah (2008)

\section{HASIL}

Kegiatan pengabdian Masyarakat dapat berjalan dengan baik dan hasil dari kegiatan yang dilakukan dapat di simpulkan sebagai berikut :

a) Masyakat terutama para ibu-ibu merasa senang untuk menjalani kegiatan ini karena dapat ilmu baru yang dapat mereka kembangkan nantinya.

b) Para Ibu-ibu dapat mengerti dengan baik untuk menggunakan alat-alat teknologi seperti mixer,Oven dll

c) Melalui kegiatan pengabdian ini masyarakat diajarkan supaya bisa memanfaatkan jagung tidak hanya di jual sebagai makanan ternak tapi bisa di olah menjadi makanan yang bernilai jual.

SOLUSI PERMASALAHAN 
Melihat penghasilan dari para petani di dusun Sempayuk sebagian besar adalah jagung, maka Salah satu solusi yang harus dilakukan kepada masyarakat atau ibu-ibu kelompok usaha tani adalah dengan melakukan kegiatan yang bersifat kewiraushaan yakni dengan melatih mereka dan membimbing ibu-ibu rumah tangga untuk bisa melakukan kegiatan yang dapat membantu ekonomi rumah tangga mereka dengan jalan mengubah pola pikir mereka untuk bisa berpikir secara wirausaha sehingga mereka tidak hanya menjual jagung dalam bentuk bijian tetapi mengajak mereka untuk melakukan kegiatan ekonomi yang bersifat inovasi dengan Melakukan pelatihan pembuatan kue dengan berbahan dasar jagung ini bertujuan agar masyarakat bisa melihat peluang lain dan hasilnya dapat di jual. Dengan harapan mereka tidak hanya menjual jagung ke Tengkulak tapi mereka juga bisa Mengolah makanan jenis kue sebagai produk turunan yang kas dari desa mereka yakni Desa Belimbing,dusun Sempayuk Luaran yang di hasilkan. Jurnal Nasional

Respon dari para ibu-ibu terhadap pelatihan ini luar biasa,itu dapat terlihat dari semangat mereka untuk mengetahui lebih dalam tentang proses pembuatan dan pemasaran kue.Dan mereka sangat aktif bertanya seputar manfaat jagung selain membuat kue.Semangat kewirausahaan dari Masyrakat di dusun Sempayuk atau masyarakat desa Belimbing terhitung sangat bagus walaupun secara Pendidikan mereka kurang memadai namun motivasi mereka yang luar biasa sehingga pemerintah perlu mendapatkan perhatian kusus kepada masyarakat di desa Belimbing ini agar mereka bisa dibimbing dengan baik sehingga suatu saat nanti desa ini bisa menjadi desa yang memberi contoh yang baik bagi desa-desa lain di kecamatan Lumar. Pemerintah harus bisa bekerja sama dengan pengurus desa supaya masyrakat bisa belajar kewirausahaan agar pola pikir mereka bisa berubah sehingga mereka bisa menggunakan jagung sebagai alat untuk melatih mereka untuk berbinis dengan baik.sehingga dapat membantu ekonomi rumah tangga.

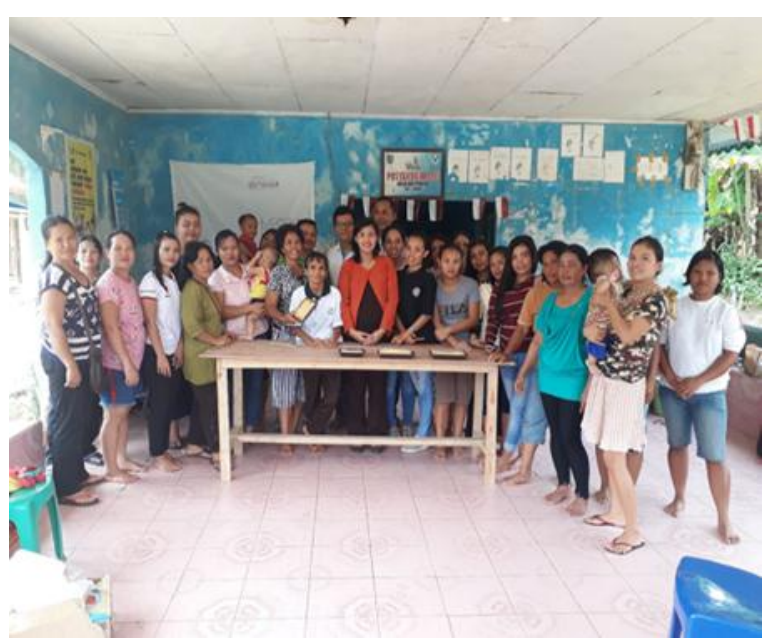

Gbr.1

Foto bersama team dari Shanti Bhuana Bersama ibu-ibu petani jagung setelah kegitan selesai.

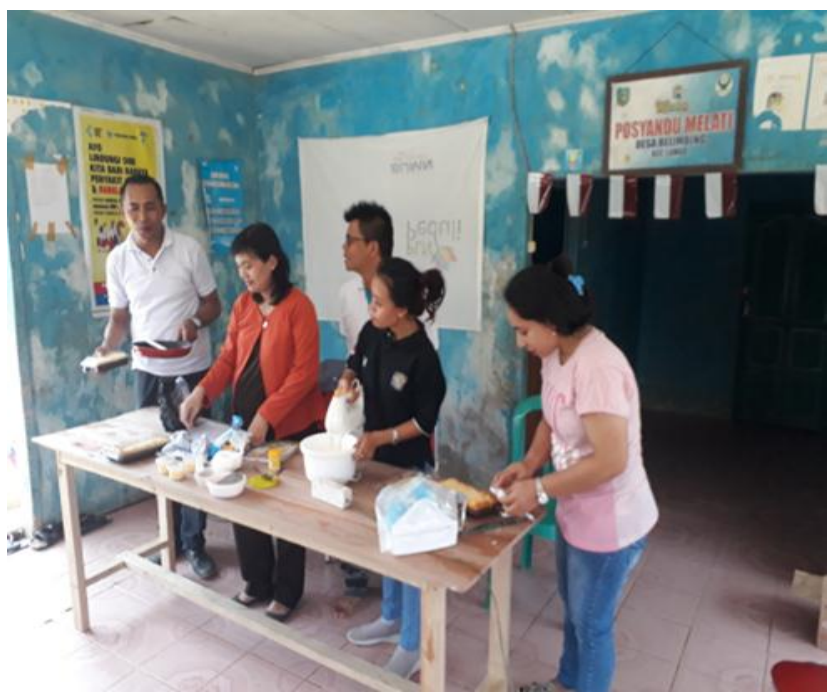

Gmbr.2 Foto dari para team dari shanti Bhuana saat memberikan pelatihan cara pembuatan Kue 


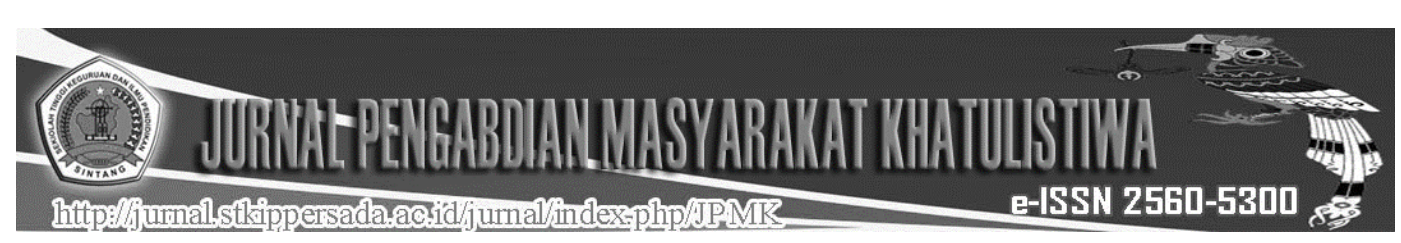

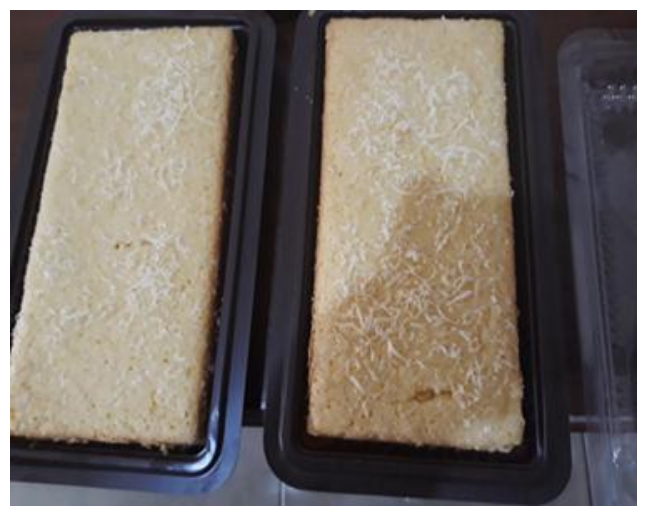

Gb 3. Foto Kue Bolu yang di hasilkan berbahan dasar jagung

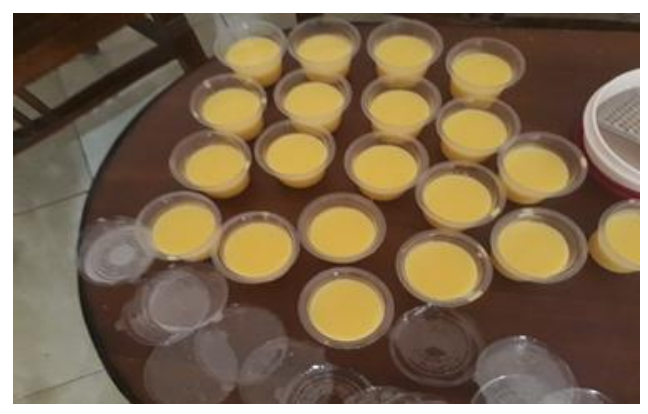

Gbr 4.Kue puding yang di hasilkan

KESIMPULAN:

Berdasarkan kegiatan yang telah dilakukan Secara garis besar hasil yang dapat disimpulkan adalah:1)Menambah pengetahuan,bagi ibu-ibu dari petani jagung serta mendapat penegetahuan tentang pembuatan kue yang berbahan dasar jagung. .2)Mereka dapat mempraktekkan ilmu yang mereka dapat untuk dijadikan lapangan pekerjaan baru serta dapat dijual untuk membantu ekonomi rumah tangga. 3)Ibu-ibu dapat mengenal alat-alat serta dapat menggunakan dengan baik. Pada kesempatan ini secara umum masyarakat terutama para ibu-ibu sudah dapat memahami dengan baik bahwa jagung tidak hanya bermanfaat untuk di jual untuk pakanan ternak tapi juga dapat di olah untuk dijadikan makanan yang dapat dijual.Harapan bagi masyarakat dusun Sempayuk agar terus belajar dan mengembangkan ilmu yang sudah di pelajari dan pengalaman yang telah mereka dapat bisa di jadikan sumber penghasilan bagi mereka untuk para ibuibu membantu ekonomi rumah tangga dalam membantu suami meringankan beban dan tanggung jawab suami untuk mencari nafkah.

\section{DAFTAR RUJUKAN}

Efendi, E. 2015. "12 Manfaat Jagung”.

Diakses pada 22 Desember 2015 melalui http://manfaat. co/manfaat-jagung.html.

Ermanita, Y. Bey, dan Firdaus L.N. 2004.

Pertumbuhan vegetatif dua varietas jagung pada tanah gambut yang diberi limbah pulp dan paper. Jurnal Biogenesis 1:1-8.

Hendriadi, A. 2013. 
Optimalisasi Kegiatan Lit

Kajibang Diklatluh dan

Corporate Management Untuk

Peningkatan Kinerja Litbang

Hortikultura. Rapat Kerja Pusat

penelitian Pengembangan Horti-

kultura Badan Penelitian dan

Pengembangan Pertanian

Jumadi. 2008. Penelitian Tindakan

Kelas. (online)

http://www.radarbanjarmasin.co $\mathrm{m} /$ berita/index.asp?berita=Opini \&id=71689. (Diakses 7 februari 2011).

Onyebinama dan onyebinama

2010,Extension education and

entrepreneurship development

in Nigerian agriculture

Agricultural Journal, 5 (2)

(2010), pp. 63-69 View Record

in Scopus

Rahman, Syamsul. 2015. “Analisis Nilai

Tambah Agroindustri Chips

Jagung" dalam Jurnal Aplikasi

Teknologi Pangan 4 U.A.U.

Onyebinama, I.C.

Surtinah. 2008. Umur Panen yang tepat

menentukan kandungan gula biji jagung manis (zea mays saccharata, Sturt). J.Ilmiah

Pertanian,4(2):1_6.............dst. 